\title{
Shifting emphasis in the educational paradigm of engineers training
}

\author{
Lyudmila Znikina ${ }^{1}$, Dina Sedykh $^{2}$, and Valery Borovtsov ${ }^{3}$ \\ 1 Doctor of Pedagogical Sciences, Professor, Head of the Department of Foreign \\ Languages* \\ T.F. Gorbachev Kuzbass State Technical University, Kemerovo, Russia \\ ${ }^{2}$ Candidate of Pedagogical Sciences, Assistant Professor of Foreign Language Department, \\ T. F. Gorbachev Kuzbass State Technical University, Kemerovo, Russia \\ ${ }^{3}$ Senior Teacher of Foreign Language Department, Postgraduate, T. F. Gorbachev Kuzbass \\ State Technical University, Kemerovo, Russia
}

\begin{abstract}
The article deals with the issues of efficient shift of cultural accents in the engineers' training concept in the context of educational environment internalization and expansion of cross-cultural professional contacts. The improvement of professional skills is considered through framing and formation of students' basic skills of multicultural communication. It is to be regarded as a main factor of the training of the new generation engineers. The authors stress on the idea that the success of academic mobility and business communication in professional community is determined by the level of future specialists' readiness to professional multicultural cooperation.
\end{abstract}

\section{Introduction}

New scientific and theoretical ideas for the professional training of future specialists are implicitly related to the innovative nature of the changing socio-cultural environment of the educational environment. The modern pedagogical community is focused on the study of problems identified by the obvious expansion of up-to-date academic exchanges and professional links $[1 ; 2 ; 3 ; 4 ; 5]$.

In this context special attention should be focused on the creation of "growth points". "The points" (based on the imperatives of the XXI century) will help to make the modern education system more effective in accordance with the long-term interests of Russia [6].

* Corresponding author: znikina@kuzstu.ru 
The economic need for a "technological breakthrough" for a competitive position in the world market determines the domestic priority industries and technologies of the country. We are inclined to believe that the development of the country is possible with the most active participation of the higher education. One of such "points of growth" in Russian education is the process of internationalization of the educational environment due to academic mobility and the expansion of business contacts in the professional community. The emphasis of the educational paradigm should be practically shifted: "we are to teach what we can do" to "we are to teach what is needed for the modern society".

In the Decree "On national goals and strategic objectives for the development of the Russian Federation for the period up to 2024", the President outlined a number of strategic objectives that are included in the key areas of educational activities of higher education institutions. One of the tasks is the need to significantly increase the number of foreign citizens studying at Russian universities in the coming years. This goal should be gained by urgent modification of the educational processes in the format of social and cultural aspects.

Taking into account the trend of increasing the number of foreign students in Russian educational institutions, it can be argued that the development of a strategy for educational and upbringing processes in the context of multicultural interaction is an important area of activity of universities $[7 ; 8 ; 9]$. In the conditions of the internationalization the issues of the educational environment are actualized. The problems of integration processes in the focus of cultural studies, sociology, psychology, pedagogy acquire new horizons $[10 ; 11$; $12 ; 13 ; 14]$. It became obvious that the previous model of the graduate-engineer's training, primarily concentrated on the technical specialty, has been shifted to the model of the personal development of the future specialist.

We associate the change of emphasis in the educational paradigm of engineers' training with the disclosure of the possibilities and unused potential of higher education in the culture-oriented content of the professional training of future specialists. At the same time one of the basic terms was the concept of cross-cultural communication in professional activities.

It should be noted that the culture-based analysis of this phenomenon is not the purpose of our article - these issues are mostly too specific. The main goal of our research is to identify, understand and advance arguments for the peculiarities of the modern educational processes in multicultural environment. This is a certain theoretical and practical difficulty of approaches to the development of educational technologies. So, we represent the professional and communicative competence of students as a tool for the managerial, organizational and personal development of a future specialist $[15 ; 16 ; 17]$.

It is necessary to emphasize once again that the success of academic mobility and business contacts in the professional community is determined by the level of readiness of specialists in the new format for professional interaction. Framing communicative competencies is one of the most important task to emphasize the improvement of professional skills through the development of personal language culture. Nowadays that is also a key vector for training specialists. Undoubtedly, the ability to communicate in a multicultural professional environment is the key to the success of constructive business communication.

\section{The results and discussion}

The study of the multidimensional concept of the educational environment made it possible taking into account modern trends in education, to place a special emphasis on understanding the multicultural educational environment of the university. This phenomenon is considered as a space where the open manifestation of ethnic and cultural, communicative interpersonal relations of the educational process is identified. This feature 
justifies the choice of a participatory approach to the organization of educational processes in a multicultural environment. We consider that the participatory approach, as a methodological basis for teaching students in a multicultural environment, is based on partnership and the development of cooperative activities of the participants in the educational processes.

The very concept of "participation" implies interpersonal communication, dialogue activity, cooperation, as well as, the ability and readiness for successful communication in a particular social and cultural context. Our experience of working with students of different nationalities, pedagogical observation and creative cooperation with colleagues confirm that, in the characteristics of the pedagogical support of the learning process in a multicultural educational environment, the actualization of the participatory approach is an opportunity to solve important educational problems:

- overcoming the problems of mutual respect and understanding;

- the formation of tolerance for a multicultural personality;

- the personal development in a modern multicultural society;

- the preservation of the ethnic identity of students;

- the ability to constructive dialogue / polilogue with representatives of other cultures;

- the development of the required level of communication skills.

We have to clarify that the educational environment is an open social resource that forms certain personal and professional qualities of the subjects of the educational process. The study of various approaches to the organization of intercultural dialogue allowed us to conclude that communicative strategies of interethnic communication can be developed in the learning process, "building" an appropriate intercultural dialogue. We defined this dialogue as "correct" pedagogical dialogue. Our pedagogical experience also confirms that in situations of intercultural communication, the construction of such a dialogue removes ethnic, cultural, psychological and linguistic barriers between the participants of the multicultural cooperation. The most effective approach to organizing training is participatory one. It is aimed at ensuring the implementation of linguocultural and communicative-pragmatic functions of pedagogical support of higher education. This approach allows students to overcome the threshold of misunderstanding, and sometimes a complete rejection of national and ethnocultural manifestations, awaken a benevolent interest to each other as a team, the characteristics and language of a particular culture, and develop a tolerant perception of other people.

We are to determine the basic positions according to main characteristic feature of the participatory approach to the organization of educational processes:

- providing culture-oriented educational content;

- the need to prepare teachers for professional activities in a multicultural educational environment;

$\neg$ "building" an appropriate "correct" pedagogical dialogue between the participants of the educational process in the classroom, which results in the formation of a favorable psychological microclimate and positive emotional culture in groups.

The terminological field of the concept of "educational process" in pedagogy is usually considered from three positions: the educational process as a scientific concept (design); as a procedural concept (definition of stages and algorithm of the learning process); as a functional concept (specific mechanisms and means of implementing the process). When designing the pedagogical process for the formation of extra-professional competencies of engineers, the ideas of researchers were valuable and useful for us: representing a specific mechanism and means of implementing the learning process as an algorithm for the functioning of a system set of instrumental and methodological means of achieving the goals of the learning process. 
The technological chain of the model for the formation of the studied competencies is represented by three stages: basic, actualizing and creative ones. Each of them is a specific form and method of work, an algorithm for their application, the expected result.

The first stage was characterized by a focus on the intercultural content of education and, in fact, being basic, psychological and pedagogical, it was designed in the learning chain as "acquaintance". The purpose of the basic stage of the linguodidactic model was the information accumulation of intercultural knowledge, the exchange of ethnocultural ideas. The result of the implementation of the training content corresponded to the planned expectations: the acquisition of basic knowledge of intercultural communication of representatives of different cultures; relieving anxiety in communication; overcoming the barrier of misunderstanding the "alien" culture, acquiring knowledge of both verbal and non-verbal communication of a multi-ethnic nature.

The second stage of the educational process is content-technological (actualizing). The organization of training at this stage was based on modeling situations of intercultural partnership, options for professional-communicative and "dialogue of cultures" in simulated educational blocks. The most active forms of education at the stage of forming the competencies of intercultural partnership, assertive and tolerant behavior were "casestudy" situations, projects, role-playing games, presentations. Such forms of work with students as lesson-interaction, extracurricular work with the development of creative activities, and individual counseling proved to be effective. The attraction of the so-called "training in partnership" provided by a participatory approach to the organization of the educational process was effective. The result is evident: the development of positive interdependence, tolerance, the ability to work in a team, an objective assessment of his/her own achievements.

And, finally, the third stage, communicative-practical (creative). This stage was characterized by the active work of the teacher with students not only in the classroom, but also by the organization of various creative extracurricular meetings (including interactive social events cross-ethnic by nature). The most effective activities were creative master classes at the actualizing stage of training. The teachers can be regarded as mediators of a particular culture. The attractive forms were self-presentations, essays, quests etc. The trainees had a great possibility to demonstrate the skills of multicultural communication.

Training of specialists is most effectively implemented through such didactic methods and techniques as:

- independent modeling of business situations - to identify and analyze the causes of problem situations in intercultural communication; to master the basics of effective communication;

- preparation of lexical and grammatical material for a specific situation given by the teacher in the form of a case-study training - for the formation of behavioral communication skills of business intercultural communication;

- collection and selection of information on a specific topic of discussion - for example, to discuss the peculiarities of the Russian mentality for successful communication with a business partner; in determining linguistic and cultural stereotypes and communicative management styles among representatives of other cultures;

- searching for information or creative compilation of a thematic role-playing game - to practice communicative skills of preparation and negotiation, presentations.

The overall result of the implementation of the proposed organization and content of the educational process in the formation of extra-professional competencies of future specialists in a multicultural educational environment is determined by the readiness of students for professional, communicative and tolerant behavior in a multicultural format of future professional activity. 
It is also important to take into account the level of teachers' methodological readiness for the educational process in the multicultural environment of the university.

We defined the teacher's methodological readiness for teaching students in multicultural conditions from two positions:

- a teacher as a professional in a special field of knowledge;

- a teacher as a moderator of pedagogical dialogue (polilogue) in a multicultural environment.

The study made it possible to conclude that pedagogical dialogue in a multicultural educational environment is a component of intercultural interaction, productive pedagogical cooperation of the educational process participants. On the one hand, this is a professionally directed and culturally meaningful function of the teacher, on the other hand, the reciprocal attitude (feedback) of the student as a representative of a specific ethno-cultural attitude to his environment, expressed in the degree of readiness for co-creation. This process can only be equal communication between the participants of the educational process, which is characterized by the teacher's educational function, his/her knowledge of the basics of intercultural communication. The most important function of the teacher is the development of interpersonal perception, co-creation, ethical, cultural and intercultural interaction with students in the educational process.

\section{Conclusion}

The aspect of training a competitive specialist is reasonably important. The purpose of the business communication classes is to acquire person-to-person communication skills necessary to identify common interests and achieve mutual understanding based on knowledge and full awareness. Inability to communicate and lack of communication create misunderstandings between business partners. Today any modern company activity is impossible without multicultural and communicative skills and abilities of specialists. Actually, enterprises, firms or any other business organizations must be able to successfully operate, cooperate, negotiate with employees, partners and consumers. Success is determined by mutual understanding and the ability to interact through communication.

\section{References}

1. N.I. Almazova, Professional'noe obrazovanie v Rossii i za rubezhom, 2:22,40 (2016)

2. I.E. Bryskina, Vestnik Tambovskogo universiteta, 3:83, 123 (2010)

3. L.S. Znikina, D.V. Sedykh, Problems of modern pedagogical education, series "Pedagogics and Psychology", 56:3, 49 (2017)

4. V.I. Slobodchikov, Novyye tsennosti obrazovaniya (New values of education), 7, 177 (1997)

5. K. Knapp, Interkulturelle Kommunikation. Zeitschrift für Fremdsprachenforschung, $66(1990)$

6. S.P. Kapica, S.P. Kurdyumov, G.G. Malineckij, Sinergetika i prognozy budushchego (Editorial URSS Moscow, 2003)

7. S.G.Tep-Minasova, Vojna i mir yazykov i kul'tur: voprosy teorii i praktiki mezh"yazykovoj i mezhkul'turnoj kommunikacii (Astrel, Moscow,2007)

8. A.M. Akopyanc, Universitetskie chteniya (PGLU, Pyatigorsk, 2009)

9. L.V. Yarotskaya, Lingvodidakticheskie osnovy internatsionalizatsii professional'noy podgotovki (Thesis of doct. diss. Moscow, 2013) 
10. H.D. Brown, Intercultural Press, 184 (2013)

11. A.M. Akopyanc, Universitetskie chteniya. 3, 6 (2009)

12. R. Irwing, Anthropology Matters Journal, 9:1, 11 (2007)

13. V.I. Karasik, Language of the Social Status ( GNOSIS,Moscow,2002)

14. N. Adler, International Dimentions of Organisational Behaviour (College Publishing Ohio, South-Western ,1997)

15. D. Fransis Woodcock, The unblocked manager. A practical guide to self development, 320 (1991)

16. R.D. Lambert, Education Exchange and Global Competence (Council on Educational Exchange, New-York, 1996)

17. J.D. Mayer, C.D. Cobb, Educational psychological review, 12:2, 163 (2000) 